ÉGYPTE monde arabe

\section{Égypte/Monde arabe}

15 | 2017

Migrations vues d'Égypte - mobilisations et politiques

\title{
Managing Distance: Examining Egyptian Emigration and Diaspora Policies
}

\section{Lea Müller-Funk}

\section{(2) OpenEdition \\ 1 Journals}

\section{Electronic version}

URL: https://journals.openedition.org/ema/3656

DOI: $10.4000 /$ ema.3656

ISSN: 2090-7273

\section{Publisher}

CEDEJ - Centre d'études et de documentation économiques juridiques et sociales

\section{Printed version}

Date of publication: 5 June 2017

Number of pages: $47-69$

ISBN: 2-905838-93-0

ISSN: $1110-5097$

\section{Electronic reference}

Lea Müller-Funk, "Managing Distance: Examining Egyptian Emigration and Diaspora Policies", Égypte/ Monde arabe [Online], 15 | 2017, Online since 05 June 2019, connection on 07 July 2022. URL: http:// journals.openedition.org/ema/3656 ; DOl: https://doi.org/10.4000/ema.3656 


\title{
LeA Müller-FunK
}

\section{MANAGING DISTANCE: EXAMINING EGYPTIAN EMIGRATION AND DIASPORA POLICIES}

\begin{abstract}
How do states manage emigration and the attachment of citizens living abroad to their home countries? This article sheds light on the mechanisms of emigration and diaspora policies in the MENA region by analysing the Egyptian experience. By following the emergence of Egyptian policies from a long-term historical perspective, I argue that emigration and diaspora policies are designed as a reaction to the economic situation of the sending country and the immigration policies of receiving countries.

Egypt changed slowly from a country characterised by immigration at the end of the $19^{\text {th }}$ century to a country in which emigration has become an omnipresent social phenomenon. The Egyptian state first opened up to emigration in the 1960s, and then progressively started to organise and manage labour emigration to other Arab countries from the 1970s onwards, which began to be perceived as a development strategy and tool. With ongoing emigration to Western countries from the 1980s, Egypt also began to strengthen its diaspora policies. However, unlike other countries in the MENA region that have high levels of emigration, Egypt only really made a concerted effort to integrate its citizens abroad in political terms after a massive wave of campaigning by Egyptians living abroad in 2011.
\end{abstract}

\section{INTRODUCTION}

Today, the Middle East is an area of both emigration and immigration. Labour migration continues to be one of the most dynamic economic factors in the area, and remittances sent home by migrant workers in the region exceed the value of the regional trade in goods and official capital flows 
(Thiollet 2011: 103). While the oil-producing countries of the Gulf region receive the highest numbers of immigrants, with foreign nationals making up more than $50 \%$ of their populations, other countries such as Egypt and Morocco are experiencing strong emigration flows. Emigrants have thus become - at least economically speaking - important actors for labour-exporting states in the Middle East. Emigration and diaspora policies usually emerge when states experience significant flows of emigration. Egypt is a good - and yet understudied - example of this phenomenon. Today, it is one of the world's largest emigrating countries, with around 4.6 to 8 million of its population living abroad, according to Egyptian sources, corresponding to between $6 \%$ and $14 \%$ of its population, ${ }^{1}$ and is ranked fourteenth in the world on the list of the main receivers of remittances (Migration Policy Center 2013: 3). It has slowly changed from a country characterised by immigration at the end of the $19^{\text {th }}$ century to one in which emigration has become an omnipresent social phenomenon (see Figure 1). The Egyptian state first opened up to emigration in the 1960s and then progressively started to organise and manage labour emigration to other Arab - mainly Gulf - countries. This was largely perceived as a temporary phenomenon by the Egyptian state. With the ongoing emigration to Western countries, Egypt has also begun to strengthen policies that provide its citizens abroad with closer ties to their home country.

The emergence of emigration and diaspora policies is not singular to Egypt: it is a general trend practiced by all states, to a certain degree (Collyer 2013: 327). Other countries in the MENA region that have experienced strong emigration flows, such as Morocco or Tunisia, have developed similar, and even more powerful, policies (Brand 2006, Collyer 2013b).

Emigration policies are useful tools for examining the strengthening extra-territoriality dimension of statehood and a concept of nationhood that stretches beyond a state's territory. In this article, I examine the methods the Egyptian state has employed to engage with its emigrants since the 1950s, and the ways in which emigration enters official narratives about the nation. The first part discusses theoretical approaches to emigration and diaspora policies, while the second focuses on how Egypt developed into an emigration state between the nationalist period and the 1990s, when emigration was slowly introduced into its economic strategy. The third part concentrates on Egypt's current three-fold emigration policies, with a focus on the changes that have

1. A calculation of the the numbers of Egyptians living abroad largely depend on where migrants are counted, with huge discrepencies between Egyptian sources and the data provided by receiving countries. Equally, the numbers vary between the figures issued by the Egyptian Ministry of Foreign Affairs (MFA), the Ministry for Emigration and Manpower (MME), and the Central Agency for Public Mobilization and Statistics (CAPMAS), Egypt's official statistics agency. The numbers I have cited here are taken from the MME (4.6 million in 2009) and the MFA (11 million in 2011). 
taken place since the revolution in 2011. The article argues that Egypt's emigration policies are often designed as a reaction to the economic situation of the sending country and the immigration policies of receiving countries.

Methodologically, the article is based on my $\mathrm{PhD}$ research, and comprises a literature review, a policy analysis, 21 expert interviews with officials working in Egyptian government structures, Egyptian political parties, and NGOs with links to Egyptians abroad, and 47 semi-directed interviews conducted between 2012 and 2014 with people engaged in Egyptian associations or initiatives in Vienna and Paris.

\section{STATE OF THE ART AND THEORETICAL APPROACHES}

Migration policies are usually understood to be directed towards immigration, while emigration policies are rarely studied (Wihtol de Wenden 2013: 237). A number of researchers have recently begun to investigate the theories behind the role of the state in shaping and forming emigration and the transnational attachment of their citizens living abroad (Levitt \& de la Dehesa 2003, Green \& Weil 2006, Gamlen 2008, Dufoix et al. 2010, Collyer 2013, Lafleur 2013), and this field of research has lately also touched on the Middle East (Brand 2006, Collyer 2013b). These works show that countries of emigration have become increasingly interested in their citizens abroad, and have started to perceive them as economic, diplomatic, cultural, political, and demographic resources.

Historically, the oldest democracies made a distinction between citizens living in their national territory and those living abroad, associating demos with the exercise of power and territory, and excluding nationals living abroad from political participation. The right to vote depended on the payment of taxes and residence in the national territory. This model was based on a territorial theory of identity, and assumed a close link between territory and identity. The logic was that a person could be a member of one society, but not two different societies at the same time (Dufoix et al. 2010: 24). Only since the 1960s and 1970s, with increasing global migration flows, has citizenship legislation begun to move towards a model in which allegiance to a state is possible across borders.

Some scholars have shown that states need to include emigrants in the narrative of national identity as an indispensable precondition for institutional change (Collyer 2013). For Collyer, making a distinction between an immigrant and emigrant nation is a heuristically useful device insofar as it helps us to focus on how continuous, large-scale emigration - and therefore immigration - has become historically important for the self-perception of nation-states (Collyer 2013: xiii). Gamlen (2008) has introduced the term 'emigration state' for all institutions and practices dealing with emigration. 
Lyons and Mandaville have argued that encouragement of a 'transnational nation' is often an initiative of the sending state (Lyons \& Mandaville 2012: 14) and not the migrants themselves. States therefore try to demonstrate national unity across borders and pretend - including discursively - that a united transnational nation exists even though their migrant communities abroad may be politically and religiously fragmented. By using the example of Palestine, Hanafi (2006) has demonstrated that a new model of 'extraterritorial' nationstate emerged after 1948, characterised by flexible citizenship that attributes nationality and citizenship to Palestinians living outside Palestine. A similar concept of the nation-state has been mobilised by Lebanese nationals seeking to establish a perception of Lebanon as a Christian country. This strategy attempts to reintegrate Lebanese emigrants - who are to a large extent Christian - into the political life of the country, defending the ius sanguinis in Lebanese nationality law (Jaulin 2006). The extension of political rights to citizens abroad and the adoption of external voting policies would seem to be a logical consequence of this conception of nationhood. Lafleur's most recent book (2013) shows that the number of states that have adopted external voting has indeed boomed in the last two decades.

Several attempts have been made to map state policies directed at emigrants. For example, Levitt and de la Dehesa distinguish among five different measures that can tie nationals living abroad to their home countries. These are 1) bureaucratic institutions representing nationals living abroad, 2) investment policies to attract remittances from nationals abroad, 3) the extension of political rights, 4) the extension of state protection to nationals abroad, and 5) symbolic policies including cultural festivals, sports events, and the promotion of hometown organisations (Levitt \& de la Dehesa 2003: 589-598). Gamlen (2008), on the other hand, distinguishes among three types of 'diaspora mechanisms' according to the degree to which states attempt to tie their nationals abroad to them. The first type, 'diaspora building', includes measures for cultivating and recognising a diaspora (for example, maintaining national culture abroad, web portals for expatriates, the establishment of dedicated bureaucratic structures such as consular departments and migrant associations, and statistical procedures to quantify communities abroad). The second type, 'diaspora integration', attempts to extend political rights to emigrants (including external voting rights, special legislative representation, and consulting expatriate councils or advisory bodies) and civil and social rights (for example, social security benefits such as pre-departure services, extensive bilateral agreements, health, welfare, and education services, and national language teaching in the destination country). Thirdly, some states also try to 'extract obligations' from their diasporas (expatriate taxes, targeted investment policies to facilitate remittances, and encouraging migrants to contribute their skills towards the economic growth of their country of origin). 
In this article, I distinguish analytically between emigration policies, which I define as policies facilitating emigration (such as the abolition of exit visas, labour migration agreements, specialised labour agencies abroad, and the channelling of remittances), and diaspora policies, for which I rely on Gamlen's definition of a particular subset of emigration policies that aim to tie citizens abroad more closely to their country of origin.

In the following sub-chapters, I demonstrate how these two categories relate to the Egyptian case study, and show that Egypt differentiates its policies among its various emigrant populations. First, I focus on how Egypt progressively included its emigrants in its narrative of national identity in the second half of the $20^{\text {th }}$ century, in particular by modifying citizenship and emigration policies. This change was related to Nasser's policy of increasing Egypt's political and cultural capital by exporting Egyptian schoolteachers to the rest of the region, and to the fact that Egyptian emigration to other Arab countries began to be perceived as a major feature of the Egyptian economy. Second, I analyse Egypt's modern emigration approach and discuss its post-2011 change from 'diaspora building' to 'diaspora integration'. I argue that this change in policy is linked to the presence of Egyptian emigrant communities in Western countries and the specific political context of the region, with the Arab Spring giving rise to a push for more direct political participation for Arab diasporas.

\section{THE EMERGING EGYPTIAN EMIGRATION STATE}

In the period between 1956 and 2000, Egypt changed from a restrictive emigration system under Nasser to a country characterised by massive mostly economic - emigration. During this period, it focused most of its efforts on emigration policies that facilitated the outflow of labour. Under Nasser, it first encouraged the return emigration of schoolteachers, with the logic of increasing Egypt's political and cultural capital in the region. In the 1960s and 1970s, faced with the increasing role of the Gulf states as potential employers of surplus labour in the region, the Egyptian state officially introduced the legal right to leave the country, followed by the development of the first governmental institutions dealing with emigration. Under Sadat's and Mubarak's presidencies in the 1980s and 1990s, an emigration policy was established that clearly distinguished between 'temporary' migration to Arab countries and 'permanent' migration to Western countries, and their differing emigrant populations. 


\section{NASSER'S RESTRICTIVE EMIGRATION POLICY (1956-1967)}

With the emergence of Arab nationalism during the Nasserist Era, the state adopted a defensive attitude towards emigration. In fact, it is rare to find any reference to migration by government officials or in the media prior to the 1960s.

In 1952, just after the Revolution, a new law on Egyptian nationality (Law 391) was adopted that amended the first decrees on Egyptian nationality, which dated back to 1926 and 1929, and referred to 5 November 1914 (which is regarded as the day on which Ottoman sovereignty over Egypt and Cyprus came to an end) as the watershed for Egyptian nationality. Ottoman subjects residing in Egypt on and after that date and up until 1926 were to be considered Egyptian nationals. Others had to apply for Egyptian nationality, and had to be born on Egyptian soil in order to be granted it. In the 1929 Decree-Law, the pre-eminence of ius sanguinis was upheld (Article 5), while a particular case of ius soli was introduced for children born in Egypt of foreign fathers who resided in Egypt but were born in a country in which the majority of the population was Arabic-speaking or Muslim (Article 6). The 1929 law thus only granted Egyptian nationality if there was a common cultural, linguistic, or religious background, and did not admit all foreigners as citizens through ius soli, as the newly-passed Turkish nationality law did (Parolin 2009: 80-81).

Law 391/1952 required an even stronger territorial attachment to Egypt for the acquisition of nationality than had previously been the case (continued residence since 1900, regardless of Ottoman nationality), while Egyptian nationality could be withdrawn to protect the national community from "disloyal nationals, like Zionists and others convicted of treason against Egypt" (Article 1). It also introduced the first legislation for Egyptians migrating abroad, reflecting the fact that emigration as such was not considered desirable by the Nasser government: Article 19 stated that nationals who left the country for six months and had no intention of returning would lose their Egyptian nationality (Parolin 2009: 82).

Between the 1950s and 1967, migration remained restricted by a number of barriers, such as the law on conscription (taklîf). In the early 1960s, a mandatory work assignment system was applied to graduates in professions where there was the greatest need. This meant that the government would specify a number of professions and groups who were barred from emigration, such as engineers, doctors, and technicians. For all others, emigration was allowed on request if a work permit was obtained from the government; however, this was handled very restrictively. Furthermore, until the 1960s, exit visas issued by the Ministry of Interior were required in order to leave the country (Dessouki 1982: 55 and 61-62). 
One exception was educational emigration, which was facilitated by the Egyptian state. During the 1950s and 1960s, many Arab countries started investing in modern educational infrastructures and were faced with a severe shortage of qualified teachers. In 1951 and 1952, the Egyptian government introduced a government-to-government secondment programme to facilitate circular labour migration. Every trained Egyptian teacher below the age of 50 could apply for secondment abroad for four years, after which they would have to work in an Egyptian school for four years. The objective of this policy was to support other Arab countries - in line with pan-Arabist ideology - and increase Egypt's political and cultural capital abroad at the same time. As a consequence, the number of seconded Egyptian schoolteachers increased from 280 in 1951/52 to 6,579 in 1970/71. The main beneficiary countries were Saudi Arabia, Kuwait, Bahrain, Sudan, Libya, Morocco, and Lebanon (Engman 2009: 10).

The total number of official emigrants remained low, however. Dessouki cites a report that estimates the number of total emigrants between 1962 and 1968 at a mere 13,113, 6,046 of whom he classified as migrants and 7,067 as dependent family members (Dessouki 1982: 56). However, Nasser's policies - including his nationalisation programmes - led to the gradual emigration of certain sectors of the Egyptian population, including parts of the Armenian community in 1957, some of the Coptic elite, and his political opponents, among whom were members of the Muslim Brotherhood and Egyptian communists. The Israeli-Palestinian conflict and the first Arab-Israeli war in 1948 also triggered the emigration of may members of the Jewish community between 1948 and 1950 and after 1956.

\section{ESTABLISHING THE RIGHT TO LEAVE (1967-1970s)}

The period between 1967 and the 1970s was crucial for Egypt and its emigration policy. The military defeat by Israel in 1967, the beginning of Sadat's economic liberalisation policy (infitâh), and the Camp David Agreement (1978) led to a loss of influence in the region. At the same time, the Gulf States began to play a more important role in the region, both economically and politically. The 1973 oil crisis resulted in a sharp increase in oil prices, and was followed by ambitious development programmes in Arab oil-producing countries.

These factors triggered massive labour migration flows towards these oil producers, but it remained largely non-institutionalised in the Gulf. The initial clear preference for Arab immigrants in the Gulf labour market - influenced to a large extent by pan-Arab ideology - was for the most part not formalised in migration quotas or bilateral agreements (Thiollet 2011: 110). Work migration to the oil-producing Gulf states was organised gradually through a series of practices known as kafâla (literally 'bond' or 'guarantee'), which introduced 
a novel work policy. The management of foreign workers was delegated to individual Gulf citizens, and in order to live and work in the Gulf, all foreigners needed a kafîl - a sponsor - who assumed full social, economic, and legal responsibility for the employee during the contract period. The kafîl was also responsible for expatriating the employee on termination of the contract at his or her own expense. Work-related immigration was thus conceptualised as being temporary, and expatriate workers were obliged to leave the country at the end of their contract. All these aspects made permanent settlement close to impossible. These migration flows also happened in the context of population growth and increasing unemployment rates in Egypt: Egypt's population increased quickly, doubling from 9.7 million in 1897 to 19 million in 1947, and doubling again between 1947 and 1976 (Zohry 2006: 1).

As a result of these new migration flows to the Gulf and Egypt's strong population growth, the period from 1967 to the 1970s saw the first efforts to institutionalise emigration in Egypt. In 1967, the Ministerial Committee for Manpower, which had been established three years earlier to develop policies on emigration and consider applications for emigration from persons with graduate degrees, issued a major policy statement that shaped the guidelines of Egypt's migration policy for years to come. It recommended that emigration should be seen as a legitimate political solution for reducing pressures on the Egyptian job market, and emphasised the importance of a consistent migration policy. Its suggestions included encouraging work abroad, gathering information on foreign labour markets (especially their need for agricultural labour), easing bureaucratic emigration processes, and adopting procedures for maintaining contact with Egyptian emigrants abroad. In 1969, an Emigration Department was established within the Ministry of Foreign Affairs with the objectives of keeping in contact with Egyptians working in other countries, monitoring work opportunities abroad, and developing bilateral agreements with receiving countries (Dessouki 1982: 55-56).

Following Nasser's death in 1970, Egypt's new president, Anwar el-Sadat, placed additional emphasis on a more liberal emigration policy. Migration began to be perceived as a major element of the Egyptian economy, which from that time on was built on four elements: oil, revenues from the Suez Canal, tourism, and emigration (Ged 1985: 494).

Article 52 of the 1971 Constitution made emigration a constitutional right of citizens, stating that "all Egyptians are granted the right to emigrate and to return home". Exit visas were abolished in 1974. The new nationality law of 1975 no longer punished Egyptians with loss of nationality for leaving the country, and Egyptians living abroad were entitled to transmit their Egyptian nationality to their children, which meant that the law granted Egyptians the right to hold dual citizenship. With regard to employment, civil servants were given the right to re-employment in their previous positions if they decided to return to Egypt within two years of resigning (Law 73/1971). Emigration in the educational sector continued, with emigration quotas for certain - much 
needed - professions. The number of seconded teachers almost tripled in three years from 6,579 in $1970 / 1971$ to 18,035 in $1972 / 73$ (Engman 2009: 16).

These more liberal policies introduced a new emigration model that accelerated the scope of labour emigration, especially to the Gulf states, and in particular to Saudi Arabia, turning Egypt into one of the first labour-exporting countries in the world at the time. According to the 1976 census, the number of Egyptian emigrants had increased to about 1.4 million (Zohry 2003b: 132).

\section{THE INTRODUCTION OF EGYPT'S TWO-FOLD EMIGRATION POLICIES IN THE 1980s AND 1990s}

At the beginning of the Mubarak era in the 1980s, a two-fold emigration policy was introduced that clearly distinguished between 'permanent' and 'temporary' emigration, a distinction that remains partially valid to this day. In particular, the first law of this period dealing with emigration (Law 111/1983) is still the main law governing emigration.

These changes in emigration policy were a direct result of the deterioration of the Egyptian socio-economic model at the time. After an initial rapid increase in GDP of 8\% per year between 1970 and 1980, the Egyptian economy stagnated for years, despite massive - mostly American - outside aid. The first period of the infitâh policy (1974-1981) resulted in a certain enrichment of society, but did not resolve the country's major structural problems persistent inequality, poverty, population growth, lack of job creation, and the weakness of the industrial and agricultural sectors. The 1978 structural adjustment plan progressively disengaged the state as a public employer (Richards 1984: 324-325). Here, the new temporary emigration model served as something of a replacement of Nasser's welfare policy, and presented emigration as a model of success and as an opportunity to earn money rapidly. Writers and film makers of the time contributed to this new enhanced view of emigration by depicting success stories of Egyptian plumbers becoming millionaires in the Gulf (see also Cantini \& Gruntz 2008).

Law 111/1983 introduced a clear distinction between permanent and temporary migration, defining a permanent migrant (muhâjir hijra dâ'ima) as someone who obtained nationality or a permanent residence permit in a foreign country (requiring the approval of the receiving countries), remained abroad for at least ten years, or was in possession of an emigration permit from the Ministry of Emigration Affairs (Article 8). A temporary migrant (muhâjir hijra mawqûta) was defined as an Egyptian citizen who was not a student or a seconded employee, and who lived and worked abroad for more than one continuous year but who had not applied for the permanent emigration procedure (Article 13). 
For the first time, Law 111/1983 also introduced duties of the state in terms of maintaining contact with Egyptians abroad, such as establishing posts in Egyptian Embassies for officials with responsibility for maintaining contact with Egyptians abroad, establishing Egyptian associations, cultural clubs, and Arabic language training centres, and organising cultural events abroad (Article 2). It also made major concessions in terms of nationality, and reaffirmed the right to retain Egyptian nationality when emigrating. In particular, the children of permanent migrants born abroad are considered to be Egyptian citizens if their parents have preserved their own Egyptian nationality. Moreover, any Egyptian citizen who emigrated before Law 111/1983 and had lost his or her citizenship now has the right to regain it (Article 20). In 1986, the holders of dual nationality were excluded from having to do military service. Law 111/1983 also attempted to make investing in Egypt's economy attractive by exempting emigrants' deposits in Egyptian banks from all taxes, and by treating investments in Egypt by Egyptians living abroad as foreign investments, with all the advantages this entailed (Article 15).

The attempts to integrate Egyptian emigrants into the narrative of the national identity also become clear from the terminology used in Law 111/1983. In its text, Egyptian emigrants are either termed al-misrîyûn fi-l-hârij (Egyptians abroad) or muhâjirûn (emigrants). The verb hâjara denotes the act of emigration in Modern Standard Arabic, but it also incorporates the sense of refraining or keeping away from something (Wehr, 2011: 1019), thus adding to the imagery of a continuing link to the place one migrates from. Terms such as 'diaspora' (shatât) or even 'community' (jâliya), which create the opposite idea of permanent settlement abroad, do not appear in the text. The Arabic word for diaspora - literally meaning 'dispersion' - continues to have negative connotations in Egypt, and is often still linked to the history of the Jews and Palestinians (Pagès-El Karoui 2012: 97-98). In contrast, Law 111/1983 refers to the new generations (ajyâl) born abroad and the children of emigrants (abnâ' muhâjirîn), creating the idea of a connected, transnational nation. This also becomes apparent if one looks at how emigration statistics are compiled in Egypt: the children and grandchildren of (one or two) citizens born in another country still count as nationals even if they have officially given up their original citizenship. ${ }^{2}$

These steps can be interpreted as a first move towards 'diaspora building' by the Egyptian state by the establishment of measures that cultivate and recognise an Egyptian presence abroad, but these measures have not been

2. Migrants themselves, however, distinguish beween muhâjir (emigrant, migrant) and musâfir (traveller) when they refer to themselves in Egyptian dialect, depending on whether they perceive their settlement as permanent or temporary. Equally, Egyptian officials abroad use the term il gâlya il-masriyya bi-l-hârig (the Egyptian community abroad) to refer to Egyptian expatriate communities. 
implemented in the same way in all host countries. While policies towards established Egyptians in the West were marked by strong institutionalised ties, those towards Egyptians in the Arab world were neglected (interview Ayman Zohry, migration scholar, AUC, 05/09/2012). Tsourapas's research shows that although Egyptians in the West were courted by the state - for example, with regular sponsored trips back to Egypt and grants to study in their new host country - attempts to represent Egyptian emigrants in Arab countries were minimal: as far as these countries were concerned, the state's involvement in regulating the outflow of Egyptian labour had diminished by the 1990s, and non-governmental agencies had taken over the role of securing contracts for Egyptian workers. These contracts were often sold to Egyptians at exorbitant prices (Tsourapas 2015: 2200). Furthermore, the Egyptian state repeatedly refused to intervene in instances of severe human rights violations and labour abuses in the Gulf (personal interview SM, Egyptian human rights activist, Cairo, 17/09/2012). This also ties in with the varying profiles of Egyptian migrants in Arab and Western countries. Migration to Arab countries comprises both highly-skilled and unskilled persons, from scientists and technicians to production workers, and is extremely male-dominated (Zohry 2003a: 33). Egyptian migration to the West, on the other hand, is perceived as consisting of better-educated Egyptians than those migrating to the Arab Gulf, and tends to be family-based. It includes Egyptians who migrated in the 1960s and 1970s as a silent protest against Nasser's Socialist regime, Egyptians who were sent to study abroad by the Egyptian government and preferred to stay there after completion of their studies, and a number of successful businessmen. (Zohry 2009: 5-7).

I argue that the diverse migration profiles and the differing immigration policies of the destination countries shape the kind of policies Egypt applies vis-à-vis the various host countries to a large extent. As naturalisation and permanent settlement has become almost impossible in all major Arab destination countries and political rights have been largely ignored, the Egyptian government has focused on sending emigrants across the region without any effort to incentivise their return or strengthen their emotional ties to Egypt. In Western countries, the situation is completely different: these migrants - who are often perceived as the core of the 'brain drain' phenomenon - enjoy the political freedom to criticise the Egyptian government from abroad and also have the opportunity to acquire citizenship of their the host country. The strategy of the Egyptian state has therefore been one of co-optation and control, with increased attention being paid to cultural associations that are financially and politically dependent on the Egyptian government, state-funded trips back to Egypt, and language classes for second-generation Egyptians. 


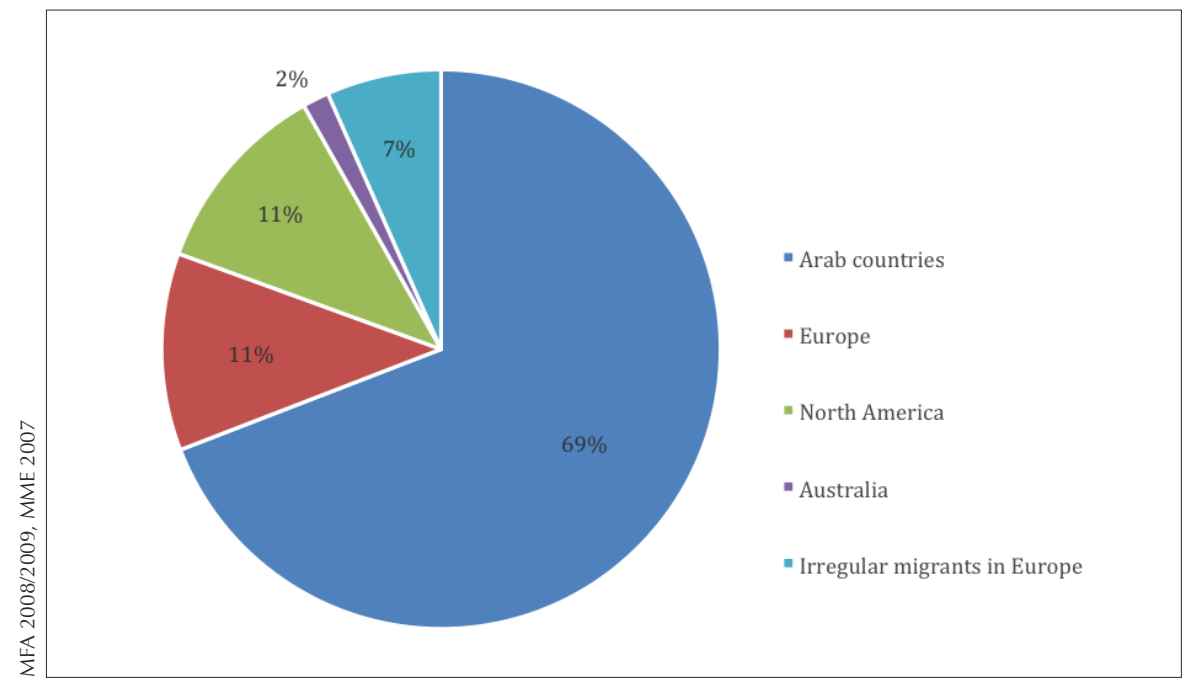

Figure 1: Distribution of Egyptian emigrants in receiving countries / regions (\%)

\section{EGYPT'S CONFLICTUAL}

\section{AND CONTRADICTORY EMIGRATION POLICIES IN THE 2000s}

Since the 1990s, Egyptian emigration flows have become more diversified, with changing migration patterns in the Middle East and increasing irregular migration to Europe. In this context, Egypt has pursued a three-fold policy. On the one hand, it has continued its dual approach towards 'temporary' emigration to Arab countries (focusing on emigration policies), and 'permanent' emigration to Western countries (focusing on diaspora policies). The aftermath of the Arab Spring revolution represented an important step forward for Egypt's diaspora policies because Egypt granted political rights to Egyptians abroad, thereby moving from a system of 'diaspora building' to a system of 'diaspora integration' after 2011. On the other hand, it introduced policies to combat irregular (transit) migration and human trafficking, in close cooperation with the European Union. Egyptian irregular migrants in Europe are mostly ignored at a policy level.

\section{THE DIVERSIFICATION OF EMIGRATION FLOWS AND THE EMERGENCE OF IRREGULAR MIGRATION}

With the decrease of oil prices in the 1980s and the decline of the pan-Arabist ideology, the Gulf states started to replace Arab work migrants with cheaper labour from South-East Asia, and from the 1990s on they began to develop labour market 'indigenisation' policies with the objective of 
increasing the percentage of native workers and employees on national labour markets. An increasing number of jobs were now reserved for Gulf state citizens, and entry and work requirements for foreigners were tightened up (Beaugrand 2010). Finally, the political crisis following the Gulf War in 1990 and 1991 led to significant backflows of migrants from Iraq, Jordan, Bahrain, Kuwait, and Qatar to Egypt.

This combination of factors triggered a restructuring of Egyptian emigration destinations. The impossibility of migrating to Iraq - which at its peak had received $45 \%$ of Egyptian migrant workers - slowly changed migration flows towards Kuwait, Jordan, Libya, and, most of all, Saudi Arabia. Not only did the destination countries in the Middle East change, moreover, but migration flows to Western countries increased at the same time, particularly to the U.S., Australia, and Europe.

Since the 2000s - and the economic crisis in particular - the Gulf state countries and Saudi Arabia have cut the number of work contracts for Egyptian migrants even further. At the same time, the degrading working conditions for migrants in the countries of the Gulf Co-operation Council (GCC) have been repeatedly discussed in the Egyptian media, which have increasingly challenged the ideal of the successful emigrant returning from the Gulf. With declining work opportunities in the Gulf and persistently high unemployment rates in Egypt, the 2000s witnessed an accelerated increase of - partly illegal - Egyptian migration to Europe, especially to Italy and France.

\section{EGYPT'S THREE-FOLD CONTEMPORARY EMIGRATION APPROACH}

How did Egypt deal with this new reality? On the one hand, the Egyptian government continued to pursue its dual approach to 'permanent' and 'temporary' emigration, presenting temporary emigration as a solution to high domestic unemployment rates, despite precarious working conditions in the Gulf countries. Institutional efforts focused on encouraging labour migration to the Gulf and on maintaining links with 'permanent emigrants' in Western countries, just as before.

The 1990s saw a restructuring of the Egyptian institutions concerned with emigration. Beginning in 1996, responsibility for emigration issues was transferred from the Ministry for Emigration Affairs to the Ministry of Manpower and Employment, which was renamed the Ministry of Manpower and Emigration (MME). Within this Ministry, the Emigration Sector was made responsible for defining new policies to encourage Egyptian emigration and to support Egyptians abroad. Egypt also continued to establish new bilateral agreements with Arab countries (Tunisia in 2001, Sudan in 2003, Jordan and Saudi Arabia in 2007, and Libya in 2009), often combined with the objective of legalising irregular Egyptian migrants. However, the director of the Emigration Sector observed that the main tasks of "encouraging investment 
and development from Egyptians abroad" performed by the sector between 1996 and 2012 was "not satisfactory because there weren't a lot of Egyptians in Europe at that time; they were only in the Gulf, and they were mainly contract workers" (interview WF, Ministry of Manpower and Emigration, 10/09/2012). This is indicative of the fact that, again, policies were mostly understood to target emigrant communities in the West.

On the other hand, Law 111/1983 did not grant any political rights to emigrants, and Egypt did not follow the example of other countries in the region, such as Tunisia and Morocco, and strengthen its diaspora policies further during that period. In both Tunisia and Morocco, the reason for enhancing emigration - reducing unemployment and the potential for social unrest had been similar to Egypt's - but both these countries enjoyed special positions as former French colonies and had for the most part concluded labour agreements with European countries after independence (Morocco for example, with France, Germany, the Netherlands, and Belgium). According to Brand (2006: 55-56), three major developments have influenced the emergence of stronger diaspora policies in these countries. In the first place, in contrast to Arab destination countries, state and NGO institutions were established in European destination countries to protect immigrants' rights, especially in the light of growing anti-immigrant sentiment. Secondly, a series of changes allowed some degree of political participation, even without access to nationality (right of association, right to vote in municipal elections). Thirdly, European countries repeatedly hosted opposition figures and Tunisian and Moroccan political movements, who were perceived as a threat to the autocratic regimes from outside the country (such as Mehdi Ben Bark and Rachid el-Ghannouchi).

As a result, for example, Morocco designed a range of governmentsponsored institutions in the early 1970s with the priority of controlling emigrants more tightly. These included the amicales, which were associations that sought to protect Moroccans emigrants abroad but also to keep an eye on their political activities. In the 1990s, the Fondation Hassan II pour les Marocains Résidents à l'Etranger and the Ministry for the Affairs of the Moroccan Community Resident Abroad were founded. Finally in 2005, King Mohammed VI announced the creation of a new institution to engage emigrants (Conseil de la Communauté Marocaine à l'Etranger (CCME)), and gave them the right to vote (although this was only finalised in 2011). The CCME consisted of individuals appointed from the Moroccan community overseas with the intention that it would offer opinions on significant legislation (Collyer 2013: 182-187). Tunisia has gone even further: in addition to establishing one of the most extensive consular networks in France, it has - since as early as 1966 - held regular expatriate conferences in Tunis, and in 1988 established the Office des Tunisiens à l'Etranger (OTE) with the mission of developing economic, social, and cultural relations with Tunisians abroad. 
I argue that the main reason why Egypt did not develop similarly strong ties to Morocco and Tunisia was due to the specific distribution of Egypt's emigrant population: while the majority of Tunisian and Moroccan emigrants left for Europe, the major destination for Egyptian emigrants in that period was other Arab countries. Thus, in 1984, around 3.9 million Egyptians were estimated to live and work abroad, approximately 3.2 million of whom were living in Arab countries, and only 0.6 million in Western countries (Talani 2010: 71). Egyptian emigrant communities in Western countries were therefore too few in number to pose a real political threat to the regime, as Tunisia's and Morocco's had in the case of Tunisia and Morocco.

A third axis of Egypt's modern emigration policy is irregular migration to the EU. This new phenomenon - often involving the dangerous passage across the Mediterranean - has raised many unpleasant political questions for the Egyptian government. Its mere existence underscores the inability of the government to find valid solutions for the high youth unemployment rate. In 2010, for example, $52.3 \%$ of the population was under 25 years of age, of whom 25\% were unemployed (United Nations 2010). Accurate data on these migration streams are not available, but a recent study by the Egyptian Ministry of Emigration has estimated that in 2007, around 460,000 Egyptians were living in Europe in an irregular situation (Abd al-Halîm 2011). The IOM (2016) has stated that increasing numbers of Egyptian migrants are arriving in both Italy and Greece: in 2015, the numbers of irregular Egyptian migrants arriving in Greece reached almost 1,000, while a total of 1,815 landed in Italy between January and May 2016, making Egypt the tenth top "sender" country of irregular migrants to Italy.

As a consequence, the Egyptian government has officially embraced a policy of combatting irregular migration in close cooperation with the European Union, albeit without much success. Law 88/2005, for example, punishes irregular migrants or persons assisting an irregular migrant with a prison sentence of up to six months and a fine of 200-1,000 EGP. As regards human trafficking, the Egyptian government passed Law 64 in 2010, which penalises both the commission of and participation in human trafficking with high fines or long prison sentences. In addition to legal regulations, Egypt created the National Coordinating Committee on Combating and Prevention of Human Trafficking, which collaborates with all governmental and non-governmental agencies dealing with human trafficking, in 2007.

These policies have gone hand in hand with closer cooperation with European countries to combat irregular migration. In 1997, Egypt signed the first Cooperation Agreement with the EU, which was replaced by the Association Agreement in 2004 and the Egypt/EU Action Plan in 2007. The latter regulates irregular migration, agrees on bilateral cooperation for preventing and controlling irregular migration, and regulates the readmission of all Egyptian nationals residing illegally in EU Member States. In 2001, the Integrated Migration Information System Project (IMIS) was set up between 
Italy and Egypt to match potential Egyptian migrants with job opportunities in Italy. In 2002, an information programme was added to prevent illegal immigration. Egypt also subsequently concluded a bilateral agreement with Italy in 2007.

A source in the Emigration Ministry admitted that the effects of many of these projects (such as the IMIS, the Pre-Departure Orientation Programme, or the Information Dissemination for the Prevention of Irregular Migration Project) have been close to zero (interview WF, Ministry of Manpower and Emigration, Cairo, 10/09/2012). A study conducted in 2007 also concluded that the role of the formal and state media as a source of information on irregular migration was almost negligible (Zohry 2007). According to Ayman Zohry, the inefficiency of these projects is due to the lack of qualifications of staff members and the fact that the Emigration Sector relies financially on external funding (interview, Cairo, 12/09/2012).

Efforts to combat irregular migration have continued, and have been increased since the Arab Spring. With Egypt being a transit country between the Horn of Africa and the EU, irregular Egyptian emigration continues to be addressed as part of wider efforts to combat human trafficking and smuggling in the region. In the context of the humanitarian crisis in the Mediterranean especially the Lampedusa tragedy in 2013 - and the increasingly inhospitable climate towards refugees in Europe, the Khartoum Process was launched in November 2014 and adopted in December 2015. It established a platform for political cooperation between countries along the migration route between the Horn of Africa (including Egypt) and the EU, with a focus on human trafficking and smuggling. The unspoken assumptions of the Khartoum Process are that the physical burden of managing asylum seekers and migrants should rest with states in the region of origin, while the EU supports them politically and with technical and financial assistance. In June 2016, a meeting of Ministers took place in Sharm el-Sheikh, bringing together the core of the neighbouring countries of the African Union-Horn of Africa Initiative (Egypt, Eritrea, Ethiopia, Sudan, Djibouti, Kenya, Somalia, and South Sudan) in order to improve cooperation on migration management in the area and to address the challenges of human trafficking and irregular migration. In October 2016, a bill pursuing the same logic was passed by the Egyptian Parliament. It aims to "combat illegal migration and human trafficking" (mukâfahat al-hijra ghayr al-shar'îya wa-tahrîb al-muhâjirîn), and punishes smuggling with a penalty of 50,000-200,000 EGP (Article 5) — while doing nothing to address the core reasons behind irregular migration. 


\section{INTEGRATING EGYPT'S DIASPORA AFTER THE ARAB UPRISINGS IN 2011}

Most of the political debate in Egypt in 2011 revolved around internal politics, and emigration remained a minor topic; for the Egyptian emigrant communities in Europe and North America, however, the 2011 protests opened a short-lived window of opportunity for demanding more political rights in their home country. The Right2vote campaign came into being in many North American and European cities, and organised large demonstrations to demand more political participation in Egyptian politics for expatriates. $^{3}$ In April 2011, a Ministerial Legislative Committee agreed to amend the political rights law, and in November 2011, Decree No. 130/2011, which recognised that all Egyptians had equal access to their political rights, including the right to vote over the age of 18 , no matter where they lived, was issued.

Subsequently, the voting rights of citizens living abroad have become a constitutional right in Egypt. The 2012 Constitution also removed (a) the requirement of Egyptian nationality for the parents of presidential candidates' spouses, (b) the requirement of exclusive Egyptian nationality for candidates for the two Houses of Parliament, and (c) the requirement of Egyptian nationality for the spouses of those candidates. Despite this, Egyptian legislation on the right to stand as a candidate has remained restrictive: for example, a ruling in March 2011 specified that people whose parents or grand-parents had held a nationality other than Egyptian at any time could not stand as a presidential candidate (Awad 2013).

Extending voting rights to citizens living abroad might be interpreted as a policy trend towards 'diaspora integration'. This was a common trend in the Maghreb after the uprisings there, but compared to Morocco or Tunisia, Egypt's efforts to integrate its diasporas politically remained weak. The 2011 amendments to the Moroccan Constitution, for example, dedicated three articles to the full equality of Moroccans abroad, irrespective of multiple citizenship. In the Tunisian transition process, Tunisian binationals chaired the

3. Vocal calls for the right to vote from abroad had already started in 2010 with the National Association for Change led by Mohamed ElBaradei. In March 2011, two months after the revolution, the chairman of the World Union of Egyptian Expatriates suggested the formation of a political party supporting the requirements and needs of expatriates returning to Egypt. One of its primary goals was to allow Egyptians abroad the right to run for the Presidency, on the grounds that dual citizenship should not hinder political rights, including the right to run for and vote in Presidential and Parliamentary elections. The argument was that a ban on voting or running for election was not in accordance with the Constitution of 1971 or the Emigration Law of 1983. This demand was also actively promoted by the Alliance of Egyptian Americans, which argued that Egyptian expatriates supported Egypt's economy substantially and should thus be allowed to participate politically in their home country 
Electoral Commission that oversaw the 2011 elections to the National Constitutive Assembly. While the new Egyptian Constitution of 2014 did provide for parliamentary representation of Egyptians living abroad (something which had been demanded repeatedly since 2011), the law did not permit holders of dual citizenship to be candidates, thus excluding many Egyptians living in Western countries (Amir 2014). In the 2015 elections, the candidates who were nominated to represent Egyptians abroad were heavily criticised due to the fact that they themselves resided in Egypt (Saïd et al. 2015).

The post-revolutionary phase also highlighted how politically divided Egypt's emigrant populations were. The Constitution of 2012 strengthened cultural rights and protection for Egyptians living abroad in Article 56, which states that "the state represents and protects the interests of citizens living abroad, and it guarantees their rights and freedoms and holds them to fulfilling their public duties towards the Egyptian state and Egyptian society. It encourages their contribution to developing the homeland". In 2012, under the Morsi government, there were concerted attempts to link Egyptians abroad more closely to the Egyptian state . A diplomat I interviewed in Paris in 2013 told me that the tasks of consular officials shifted from surveying Muslim Brotherhood supporters to developing closer links to the Egyptian community. In this regard, he stated:

I started to meet everyone, to reunite everyone, to fix meetings with people, with Muslim Brothers, Salafists, Socialists, moderate fulûl (remnants of the old regime) and the revolutionaries, all sides. [...] However, it was impossible to create a single association for all Egyptians here. They don't talk to each other. There are immense ideological ditches between them. There is the question of age, of education and class. How to unite everybody? (interview AM, Egyptian Consulate Paris, 17/12/2013).

On a different level, officials working in Egyptian consulates in Europe repeatedly admitted that there was a large presence of Egyptian migrants without papers in France. ${ }^{4}$ This issue became an especially hot political topic during the Presidential elections of 2012, when the Consulates demanded that Egyptians first present a valid residence permit in order to exercise their right to vote (interview SA, Paris, 01/10/2013). Equally, cultural centres abroad, which answer to the Ministry of Higher Education, seem to make clear distinctions among the various emigrant groups, and to orientate their activities mainly towards highly-educated (regular) migrants (interview MI, Cultural Centre Paris, 03/12/2013). Especially after Morsi was ousted in July 2013, political events made it clear that Egyptians abroad did not form a

4. Estimates of the number of irregular migrants in France, for example, ranged from 150,000 to 250,000 . 
homogeneous group that was easy to organise and represent. The choice of which artists to invite - and hence the choice of who was considered a symbol of Egyptian culture - was highly contested in the post-revolutionary phase. This issue can also be seen in the politicisation of Egyptian cultural offices, which in some cases became venues for political confrontation. The visit of the writer and open critic of the Morsi government Alaa al-Aswany to Paris in October 2013 resulted in virulent discussions and protests, and the conflict went so far that the Cultural Centre stopped sending invitations to people who were considered to be supporters of Morsi.

\section{CONCLUSION}

The aim of this long-term analysis of Egypt's emigration and diaspora policies has been to offer new insights into the various state mechanisms used to direct emigration and influence the attachment of citizens abroad. In the course of the $20^{\text {th }}$ century, Egypt moved from a politically and educationally driven, restrictive emigration policy, to a labour exporting emigration policy from the 1970s onwards. Subsequently, the 1980s and 1990s were characterised by its efforts to introduce diaspora policies when emigration to Western countries increased.

Egypt is therefore following an international trend in which where nationstates progressively include emigrants and their children into their 'map of the nation', and seek to tie them more closely to their country of origin, and yet this article also reveals certain contradictions in the construct of a homogenous transnational nation as promoted by the Egyptian state: while it is projecting unity of interest between the government and its citizens abroad, in reality, contradictions between migrants and the national leaderships are the rule - an observation that has previously been made by Basch, Glick-Schiller and Szanton-Blanc (1997: 272).

This article also demonstrates that Egypt distinguishes among its various emigrant populations in its policies. Temporary emigrants in Arab countries are perceived as low-skilled contract labourers who will eventually return to Egypt, whereas 'permanent' emigrants are perceived as highly-skilled, wellestablished individuals who might be useful tools abroad, but might also pose a political risk to the government of the day.

The article has also highlighted how emigration and diaspora policies function in relation to the economic situation of the sending country and the immigration policies of the receiving countries. In particular, when Egypt was faced with persistently high unemployment rates, the state began to perceive emigration as a development strategy and to see the benefits of exporting labour. Furthermore, access - or non-access - to certain rights in the respective receiving countries also seems to have influenced the shape of Egypt's diaspora policies. Through the kafâla system, foreigners enjoy practically no 
political, social, or economic rights in oil-rich Arab countries, and naturalisation has become virtually impossible. The danger of 'losing' 'temporary' Egyptian emigrants is thus perceived as being less acute than is the case in Western countries, where they enjoy social and - at least to a certain degree - political rights. Irregular migrants in European countries, on the other hand, who are perceived as a new type of temporary migrants, are largely ignored on a policy level.

\section{REFERENCES}

Awad, I. 2013, "Egyptian Expatriates and the Egyptian Revolution: Egyptian Expatriates in the Egyptian Political Transformation (unpublished)", Joint Workshop on Arab Expatriates and Revolt in their Homelands, MPC/EUI and Harvard Center for Middle Eastern Studies, Harvard, 28-29 June 2013.

Basch, L.; Glick Schiller, N.; Blanc, C. S. 1997, Nations Unbound. Transnational Projects, Postcolonial Predicaments and Deterritorialized Nation-States, $4^{\text {th }}$ edition, Amsterdam: Gordon and Breach.

Brand, L. 2006, Citizens Abroad. Emigration and the State in the Middle East and North Africa. Cambridge: Cambridge University Press.

Cantini, D.; Gruntz, L. 2008, "Des nouveaux riches aux jeunes martyrs: Les évolutions de la migration de travail égyptienne au prisme de ses représentations médiatiques", in I. Farag (ed.), Chroniques égyptiennes, Cairo: CEDEJ: 79-118.

Cassarino, J.-P. (ed.) 2010, Unbalanced Reciprocities. Cooperation on Readmission in the Euro-Mediterranean Area. Middle East Institute Special Edition Viewpoints, EUI: Middle East Institute.

Collyer, M. (ed.). 2013a, Emigration Nations. Policies and Ideologies of Emigrant Engagement, New York: Palgrave Macmillan.

Collyer, M. 2013b, "The Moroccan State and Moroccan Citizens Abroad", in J.-M. Lafleur (ed.), Emigration Nations. Policies and Ideologies of Emigrant Engagement, New York: Palgrave: 175-195.

Dessouki, A. H. 1982, "The Shift in Egypt's Migration Policy: 1952-1978", Middle Eastern Studies, vol. 18: 53-68.

Dufoix, S. 2010, "Un pont par-dessus la porte. Extraterritorialisation et transétatisation des identifications nationales", in S. Dufoix, C. Guerassimoff et A. de Tinguy (eds), Loin des yeux, près du coeur. Les États et leurs expatriés, Paris: Presses de Sciences Po: 15-57.

Dufoix, S. 2010. Loin des yeux, près du coeur. Les États et leurs expatriés, Paris: Presses de Sciences Po.

El Baradei, Laila; Wafa, Dina; Ghoneim, Nashwa. 2012. "Assessing the Voting Experience of Egyptians Abroad: Post the January 25 Revolution." Journal of US-China Public Administration 9(11): 1223-1243. 
Engman, M. 2009, "Half a Century of Exporting Educational Services: Assessing Egypt's Role in Educating the Arab World", GEM Working Paper 10, http://www. ecipe.org/media/publication_pdfs/Engman_HalfCenturyofExportingeducational_ services_Egypt102009.pdf, access: 05/09/2014.

Gamlen, A. 2008, "The emigration state and the modern geopolitical imagination", Political Geography, vol. 27: 840-856.

Ged, A. 1985, "Migrations et transformations économiques et sociales en Égypte", Tiers Monde, vol. 26, $\mathrm{n}^{\circ} 103$ : 493-506.

Green, N. 2005. "The Politics of Exit. Reversing the Immigration Paradigm", Journal of Modern History 77: 263-289.

Green, N.; Weil, F. 2006, Citoyenneté et Émigration: Les politiques du départ, Paris: Éditions de l'École des Hautes Études en Sciences Sociales.

Hanafi, S. 2006, "Palestinian Refugees, Citizenship and the Nation-State", in F. De Bel-Air (ed.), Migration et politique au Moyen-Orient, Beirut: IFPO: 145-162.

Jaulin, T. 2006, "La restitution de la nationalité libanaise: enjeux juridiques et politiques", in F. De Bel-Air (ed.), Migration et politique au Moyen-Orient, Beirut: IFPO: 163-184.

Lafleur, J.-M. 2013, Transnational Politics and the State. The External Voting Rights of Diasporas, London: Routledge.

Levitt, P; de la Dehesa, R. 2003, "Transnational Migration and the Redefinition of the State: Variations and Explanations", Ethnic and Racial Studies, vol. 26, n4: 587611.

Lyons, T.; Mandaville, P. (eds.) 2012, Politics from Afar. Transnational Diasporas and Networks, London: Hurst \& Company.

Migration Policy Center 2013, MPC - Migration Profile Egypt. The DemographicEconomic Framework of Migration. The Legal Framework of Migration. The Socio-Political Framework of Migration, Consortium for Applied Research on International Migration (CARIM), EUI.

Pagès-El Karoui, D. 2012, "Egyptiens d'Outre-Nil: Des diasporas égyptiennes", Tracés, vol. 23: 89-112.

Parolin, G. 2009, Citizenship in the Arab World. Kin, Religion and Nation-State, Amsterdam: Amsterdam University Press.

Richards, A. 1984, "Ten Years of Infitah: Class, Rent, and Policy Stasis in Egypt", Journal of Development Studies, vol. 20, n4: 323-338.

Talani, L. S. 2010, From Egypt to Europe. Globalisation and Migration Across the Mediterranean, London: Tauris.

Thiollet, H. 2011, "Migration as Diplomacy: Labour, Migrants, Refugees and Arab Regional Politics in the Oil Rich Countries", International Labour and WorkingClass History, vol. 79: 103-121.

Tsourapas, G. 2015, "Why Do States Develop Multi-tier Emigrant Policies? Evidence from Egypt", Journal of Ethnic and Migration Studies, vol. 41, n¹3: 2192-2214.

Wehr, H. [2011], Arabic-English Dictionary. The Hans Wehr Dictionary of Modern Written Arabic. Edited by J.M. Cowan. [s.I.]: Snowball Publishing. 
Wihtol de Wenden, C. 2013, La question migratoire au XXIe siècle. Migrants, réfugiés et relations internationales, Paris: Presses des Sciences Po.

Zohry, A. 2003a, Contemporary Egyptian Migration 2003, International Organisation for Migration.

Zohry, A. 2003b, "The Place of Egypt in the regional migration system as a receiving country", Revue européenne des migrations internationals, vol. 19, n³: 129-149.

Zohry, A. 2006, "Egyptian Youth and the European Eldorado: Journeys of Hope and Despair", DIIS Working paper, Copenhagen: Danish Institute for International Studies.

Zohry, A. 2007, "Egyptian irregular migration to Europe", Migration Letters, vol. 4, $\mathrm{n}^{\circ} 1:$ : 53-63.

Zohry, A. 2009, The Migratory Patterns of Egyptians in Italy and France, CARIM Research Reports 2009/17, Robert Schuman Centre for Advanced Studies, European University Institute.

\section{CITED MEDIA ARTICLES}

"Egypt parliament passes bill to combat illegal migration, human-smuggling", al-Ahram, 17/10/2016, access: 18/01/2017.

Abd al-Halîm, M. "هجرة الشباب المصري غير المشروع. هروب الى الموت", al-Ahram, 01/01/2011, access: 27/07/2014.

Amir, A. "كيفية قثثيل المصريين بالخارج في البرلمان المقبل", Afrigatenews, 26/11/2014, access: 17/10/2016.

IOM, "Migrant Arrivals to Europe via Mediterranean Top 210,000 in 2016", 14/06/2016, access: 17/01/2017.

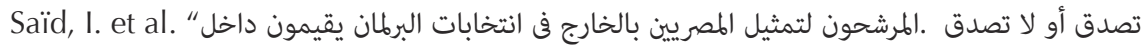

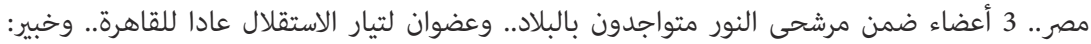
"مخالفة قانونية", al-Yawm al-sâbi', 11/10/2015, access: 17/10/2016.

\section{GOVERNMENTAL DOCUMENTS AND LINKS}

Association Agreement Egypt-EU 2001, http://eeas.europa.eu/delegations/egypt/eu_ egypt/political_relations/agreements/, access: 12/07/2014.

Egyptian Constitution 1956.

Egyptian Constitution 1971.

Egyptian Constitution 2012.

Egyptian Constitution 2014.

European External Action Service, "The Barcelona Process". http://eeas.europa.eu/ euromed/barcelona_en.htm, access: 17/07/2014.

"Human Trafficking and Smuggling of Migrants within and from the Horn of Africa", press release African Union, 03/06/2016, access: 17/01/2017. 
Law 111/1983 on Emigration and Egyptian Welfare 1983 Abroad

1983 قانون الهجرة ورعاية المصريين فى الخارج رقم 111 لسنة access: 17/01/2017.

Law 130/2011 concerning the voting of Egyptians living abroad in general elec-

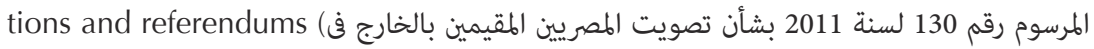
الانتخابات العامة والاستفتاء), access: 17/01/2017.

Law 64/2010 regarding Combating Human Trafficking

(قانون رقم 64 لسنة 2010 بشأن مكافحة الاتجار بالبشر), access: 17/01/2017.

Law 73/1956 on political rights (قانون رقم 73 لسنة 1956 بتنظيم مباشرة الحقوق السياسية), access: $17 / 01 / 2017$.

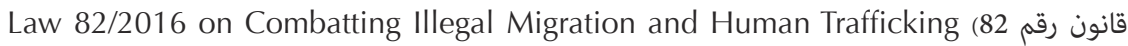
(لسنة 2016، قانون مكافحة الهجرة غير الشرعية وتهريب الهاجرين), access: 17/01/2017.

Ministry of Manpower and Emigration, Emigration and Egyptian Abroad Sector. 2006. Governmental Services: Ministry of Defense, Ministry of Education, Ministry of Interior, Ministry of Finance. Cairo.

National Coordinating Committee on Preventing and Combating Human Trafficking (The Arab Republic of Egypt). National Plan of Action Against Human Trafficking (January 2011 - January 2013). Cairo, 2 December 2013, access: 29/07/2014. 